DOI : https://doi.org/10.24123/jbt.v5i2.4032

\title{
SENSITIVITAS INVESTASI STUDI KASUS PADA PENINGKATAN KAPASITAS PABRIK GULA SRAGI PT.PERKEBUNAN NUSANTARA IX
}

\author{
Dyah Puspasari ${ }^{1}$, Suwandhi ${ }^{2}$ \\ ${ }^{1,2}$ Politeknik LPP; Yogyakarta, Indonesia. \\ Email : dyh@polteklpp.ac.id ${ }^{1}$, swd@polteklpp.ac.id ${ }^{2}$
}

\begin{abstract}
This study aims to determine the sensitivity of the increase or decrease in the selling price of sugar and drops, then the investment value, and the cost of production to the IRR obtained from the investment decision to increase the capacity of the Sragi Sugar Factory. Hypothesis testing is carried out on the results of the calculation of investment analysis which includes several commonly used parameters, namely Net present value (NPV), Internal rate of return (IRR), Profitability Index (PI), and Payback Period (PP), in this case as a comparison used The results of the IRR calculation. The results of the sensitivity study found that the selling price has the highest sensitivity, then the second is the investment value, while the cost of goods manufactured has the lowest sensitivity. The results of tests carried out on three parameters show that there is a significant change between the Selling Price, Investment Value and Cost of Production with the calculation of the IRR of an investment.
\end{abstract}

Keywords : Investation, selling price, capacity increrase, sugar factory

\section{Pendahuluan}

PT. Perkebunan Nusantara IX selama kurun waktu 10 tahun terakhir memiliki 8 unit Pabrik Gula, sebanyak 3 pabrik beku operasi, sedangkan yang 5 pabrik masih beroperasi yang tersebar di wilayah Kabupaten Sragen, Kudus, Pekalongan dan Karanganyar. Kapasitas giling masing-masing Pabrik Gula bervariasi, mulai 1.800 TCD hingga 4.000 TCD. Dari lima Pabrik Gula tersebut hanya 2 Pabrik Gula menuju kapasitas menjadi 4.000 TCD dengan menggunakan dana PMN yaitu PG Rendeng dan PG Mojo. Untuk PG Tasikmadu, Sragi dan Pangka masih dibawah 4.000 TCD. Berdasarkan best practice Pabrik Gula berkapasitas kecil cenderung mempunyai konsumsi energi dan harga pokok produksi yang tinggi. Mulai tahun 2016 PTP Nusantara IX sudah memulai program regrouping Pabrik Gula. Hal itu dilakukan untuk mengantisipasi luasan areal tebu yang belum bisa meningkat serta peningkatan kapasitas giling di 2 Pabrik Gula. Sehubungan hal tersebut PTP Nusantara IX berencana untuk meningkatkan kapasitas (upgrading) tiga (3) unit Pabrik Gula. Peningkatan kapasitas Pabrik Gula tersebut diharapkan bisa mengcover areal tebu yang ada dan diharapkan dapat menurunkan konsumsi energi dan harga pokok produksi. Revitalisasi PG Sragi ke 4.000 TCD membutuhkan tambahan areal $7.435 \mathrm{Ha}$, dengan kebutuhkan areal tambahan $4.812 \mathrm{Ha}$ 
dari luas eksisting 2.623 Ha pada tahun 2017 dari PG Sragi dan PG Sumberharjo. Lahan tambahan untuk revitalisasi PG Sragi bisa diupayakan dengan mengembalikan area historis tebu yang pernah mencapai 8.373 Ha pada tahun 2011 melalui konversi lahan dari tanaman tahunan ke tanaman tebu seluas $1.037 \mathrm{Ha}$ secara bertahap, kerjasama Agroforestry di Lahan Perhutani KPH Pemalang seluas $42 \mathrm{Ha}$, melakukan sewa lahan (IPL) yang bertujuan untuk membentuk komunitas lahan petani menjadi lahan tebu. Lahan sekitar TS beralih ke tebu, lahan eks TS tetap menjadi tebu. Program IPL dilaksanakan secara simultan ke daerah lain sehingga makin terbentuk lahan tebu secara luas. Analisis sensitivitas dilakukan untuk melihat kepekaan dari hasil uji kelayakan investasi (IRR) terhadap perubahan harga jual, nilai investasi dan beban pokok produksi. Menurut Menurut Gittinger (1986), meneliti kembali suatu analisis untuk dapat melihat pengaruh-pengaruh yang akan terjadi akibat keadaan yang berubah-ubah disebut sebagai analisis sensitivitas. Proyek pertanian pada umumnya sensitif berubahubah akibat empat masalah utama, yaitu: harga, keterlambatan pelaksanaan, kenaikan biaya, dan hasil. Analisis sensitivitas bertujuan untuk melihat apa yang akan terjadi dengan hasil analisis proyek jika ada suatu kesalahan atau penambahan dalam dasar-dasar perhitungan biaya atau benefit (Kadariah et al., 1999).Terdapat beberapa penelitian sebelumnya yang telah membahas beberapa faktor yang mempengaruhi sensitivitas suatu investasi, diantaranya; Pertama, Analisis Profitabilitas Tanaman Karet di Kebun Balong/Beji, Kalitela, Kabupaten Jepara yang dilakukan oleh Munafida, Suprapti Supardi dan Eka Dewi Nurjayanti tahun 2015, hasilnya perubahan harga jual pengaruhnya paling banyak, kemudian biaya produksi dan yang paling kecil pengaruhnya jumlah produksi. Terdapat beberapa penelitian sebelumnya yang telah membahas beberapa faktor yang mempengaruhi sensitivitas suatu investasi, diantaranya; Pertama, Analisis Profitabilitas Tanaman Karet di Kebun Balong/Beji, Kalitela, Kabupaten Jepara yang dilakukan oleh Munafida, Suprapti Supardi dan Eka Dewi Nurjayanti tahun 2015, hasilnya perubahan harga jual pengaruhnya paling banyak, kemudian biaya produksi dan yang paling kecil pengaruhnya jumlah produksi.

Penelitian kedua analisis kelayakan finansial usaha agroindustry tahu di Kecamatan Ramah Hilir Kabupaten Rokan Hulu Oleh Umay Mulyani dkk (2016). Hasilnya harga kedelai dan penurunan skala produksi. Hasilnya analisis sensitivitas kenaikan harga bahan baku kedelai $10 \%$, dan penurunan skala produksi $10 \%$ dilihat dari nilai NPV sudah bernilai negative, Net B/C 0, IRR lebih kecil dari discount factor $12 \%$, dan tidak ada payback period, artinya tidak ada pengembalian modal usaha, menunjukkan usaha agroindustry tahu Bapak Warijan tidak layak untuk dilaksanakan. Berdasarkan hasil analisis sensitivitas kenaikan harga bahan baku kedelai maupun penurunan skla produksi sangat berpengaruh terhadap kelayakan usaha atau pengembangan usaha agroindustry tahu Bapak Warijan kedepan. Penelitian ketiga M. Dion Tiara dkk (2016) Magister Agribisnis Program Pascasarja UNS meneliti dengan judul Analisis Investasi Konversi Komodits kopi ke Karet di PT Perkebunan Nusantara IX Kebun Batujamus. Hasilnya komoditas Kopi lebih peka terhadap perubahan harga jual dan biaya operasional dibandingkan dengan karet. Hal tersebut terlihat pada penurunan harga jual kopi sebesar $10 \%$ dan kenaikan biaya 10\%. Penelitian keempat Peremajaan Optimal Tanaman Karet di PT Perkebunan Nusantara IX Kebun Getas oleh Titik Widyasari,dkk (UGM, 2015). Hasilnya respon peremajaan optimal terhadap penurunan harga 5-10\% dan kenaikan biaya $5-10 \%$ secara bersamaan, menunjukkan bahwa saat optimal peremajaan Tanaman karet tetap di tahun ke-25 dan pola optimum yang tepat di \% dari luasan lahan.Hifhil Ramadhan dan Suwandhi (2019) menguji sensitivitas harga jual, biaya produksi dan jumlah produksi terhadap profitabilitas PG Tasikmadu PT Perkebunan Nusantara IX. Hasilnya membuktikan bahwa perubahan harga jual yang paling peka terhadap ROI, kemudian jumlah produksi dan yang paling rendah perubahan biaya produksi terhadap ROI. 
Berbeda dari penelitian sebelumnya, penelitian ini bertujuan untuk mengidentifikasi hal -hal berikut.(1) Apakah kenaikan atau penurunan harga jual peka atau sensitive terhadap hasil perhitungan Internal of Return (IRR)? (2) Apakah kenaikan atau penurunan produksi peka atau sensitive terhadap hasil perhitungan Internal of Return (IRR)? (3) Apakah kenaikan atau penurunan beban pokok produksi peka atau sensitive terhadap hasil perhitungan Internal of Return (IRR)?

Hasil penelitian ini diharapkan dapat memberikan kontribusi bagi para manajer Pabrik Gula, untuk mengantisipasi faktor-faktor yang dapat mempengaruhi kelayakan proyek investasi, pada tingkat mana proyek peningkatan kapasitas Pabrik Gula masih bisa dilaksanakan. Bagi akademisi untuk menjelaskan, bagaimana, kapan, dan dimana harga jual, nilai investasi dan beban pokok produksi berdampak pada perhitungan kelayakan suatu invetasi, dengan mengemukakan dampak yang dipengaruhi oleh kondisi yang berbeda.

\section{Kerangka Teori Aspek Finansial}

Aspek keuangan merupakan proyeksi keuangan dari aktivitas saat ini dan proyeksi investasi ke depan atas investasi PG Sragi yang pendanaannya bersumber dari realokasi PMN PG Comal. Aspek ini berkaitan dengan rencana perusahaan dalam meningkatkan kapasitas PG Sragi. Aspek keuangan meliputi sumber dan target pendapatan operasional serta biaya-biaya yang harus dikeluarkan meliputi biaya operasional produksi dan beban investasi yang dihitung dalam bentuk tabel lampiran proyeksi dan diuraikan dalam bentuk penjelasan dan kesimpulan. Selain itu, dibahas pula mengenai analisis kelayakan investasi untuk proyek tersebut sehingga dapat diketahui apakah proyek layak dilaksanakan atau tidak.

Penilaian kelayakan investasi proyek didasarkan atas nilai sekarang (Present Value $=P V)$ dari jumlah laba bersih sesudah pajak ditambah nilai penyusutan yang diperoleh selama umur proyek (input), dibandingkan dengan nilai sekarang dari investasi yang dikeluarkan (output). Proyek disebut layak apabila pendapatan dimaksud lebih besar dari nilai investasi, dan disebut tidak layak apabila pendapatan tersebut lebih kecil dari pada nilai investasinya. Yang dimaksud dengan umur proyek adalah umur teknis peralatan pabrik. Dalam analisa ini umur proyek diasumsikan sampai dengan nilai investasi peralatan pabrik habis disusut sehingga nilai buku sama dengan nol. Yang dimaksud dengan Proyek dalam hal ini adalah proyek pembangunan PG Sragi dengan kapasitas yang semula 3.000 TCD menjadi 4.000 TCD. Peralatan Pabrik Gula, kendaraan angkut dan gedung yang akan dibangun dan dibeli realisasinya tidak dapat dipisahkan satu sama lain, sehingga dalam analisis kelayakan keuangan proyek tersebut digabung menjadi satu proyek.

Beikut ini adalah uraian mengenai aspek keuangan:

\section{a. Rencana Keuangan}

Peningkatan kapasitas PG Sragi merupakan rencana investasi yang dilatar belakangi penataan kembali dan modernisasi Pabrik Gula yang ada di wilayah kerja PT Perkebunan Nusantara IX dan ketersediaan bahan baku tebu yang tersedia. Rencana Anggaran Biaya Proyek. Biaya proyek yang dibutuhkan meliputi biaya investasi. 


\section{b. Rencana Sumber Dana}

Sumber dana proyek berupa kebutuhan biaya investasi yang diperoleh dari Penyertaan Modal Negara (PMN).

\section{c. Proyeksi Keuangan}

Di dalam proyeksi keuangan terdapat asumsi-asumsi yang relevan atas aktivitas perusahaan saat ini maupun target-target yang akan dicapai untuk mengukur kemampuan perusahaan dalam memenuhi kewajibannya kepada pihak ketiga, serta mampu memenuhi kebutuhan operasional perusahaan. Asumsi-asumsi tersebut meliputi asumsi rencana hari giling pabrik, produksi gula milik PG, kebutuhan bahan baku tebu, harga jual gula dan tetes serta asumsi-asumsi lain yang relevan.

Proyeksi keuangan yang menggambarkan mengenai rencana dan target-target aktivitas PG Sragi di masa mendatang tertuang dalam lampiran proyeksi pada laporan ini meliputi, antara lain:
a. Rencana investasi
b. Rencana perolehan gula dan tetes milik PG
c. Target penjualan
d. Beban Pokok Produksi
e. Proyeksi Arus Kas (Cash flow).

Dari aspek keuangan, untuk menganalisis suatu investasi dalam rangka memilih investasi yang akan dijalankan diperlukan informasi-informasi yang berkaitan dengan hal berikut:

\section{a. Biaya (costs) investasi}

Biaya suatu investasi (Capital Outlay/Initial Cash Outlay) pada dasarnya merupakan jumlah arus kas bersih yang dikeluarkan untuk memperoleh suatu aset tetap. Biaya ini mencakup biaya persiapan atau perijinan (pre-operating expenses), bila diperlukan, harga perolehan aset tetap sampai dengan siap dioperasikan, biaya training, dan penambahan investasi di dalam modal kerja bila diperlukan.

\section{b. Estimasi arus kas yang diharapkan}

Estimasi arus kas ini mencakup arus kas yang diharapkan terjadi dari kegiatan operasional selama umur ekonomis maupun arus kas masuk yang terjadi pada akhir umur ekonomis investasi (terminal cash flow).

\section{c. Estimasi risiko arus kas keluar}

Setiap investasi mempunyai tingkat risiko yang berbeda dari investasi lainnya. Untuk menaksir risiko arus kas yang diinvestasikan, diperlukan informasi tentang probabilitas distribusi dari arus kas. Semakin tinggi variabilitas arus kas berarti semakin tinggi ketidakpastian atas hasil yang diperoleh, yang berari juga semakin tinggi risiko yang dihadapi. Dalam mengakomodasikan risiko ini terhadap arus kas, risiko tersebut dapat diakomodasi dengan perhitungan arus kas artinya, arus kas tersebut telah memperitungkan risiko variabilitas.

\section{d. Tingkat cost of capital}

Cost of capital merupakan tingkat bunga yang akan digunakan untuk mendiskontokan atau menghitung nilai sekarang (present value) dari arus kas suatu investasi. Besar 
cost of capital ini dipengaruhi oleh tingkat risiko investasi dan besarnya tingkat bunga tanpa risiko (risk-free rate). Dalam kasus ini menggunakan pendekan tingkat Cost of Equety, karena invetasi suluruhnya menggunakan dana PMN.

\section{e. Present value arus kas yang diharapkan}

Arus kas yang terjadi pada periode yang berlainan selama umur ekonomis investasi, termasuk terminal cash flow, harus dihitung present of value-nya. Present value atas arus kas yang dimaksudkan untuk memperoleh taksiran atas nilai suatu asset atau investasi bagi suatu perusahaan. Perhitungan ini harus dilakukan karena investasi ini umurnya lebih dari satu tahun.

\section{f. Perbandingan Present value arus kas dan intial cash outlay}

Present value dari arus kas dibandingkan dengan cost dari investasi. Selisih antara present value atas arus kas dan initial cash outlay atas investasi disebut net present value. Apabila present value arus kas melebihi costs-nya (net present value positif) maka investasi tersebut dapat diterima. Sebaliknya apabila Present value arus kas lebih kecil dari costs-nya maka net present value negatif investasi tersebut ditolak.

\section{Analisis Sensitivitas dan Hipotesis}

Analisis sensitivitas atau kepekaan, kenaikan harga input tanpa di ikuti kenaikan harga produk, sehingga tingginya biaya yang harus dikeluarkan serta terjadi penurunan produksi yang menyebabkan pendapatan usaha berkurang. Analisis sensitivitas dilakukan terhadap komponen yang menimbulkan kenaikan biaya, dan mengakibatkan penurunan produksi yaitu:

a. Analisis sensitivitas terhadap peningkatan Harga Jual Gula dan Tetes.

Gula dan Tetes merupakan produk utama dari hasil olah Tebu yang bisa dikonsumsi langsung atau diolah lebih lanjut untuk Tetes menjadi Ethanol dengan demikian harga jualnya kemungkinan berubah sewaktu-waktu. Perubahan harga gula maupun tetes diproyeksikan sebesar $10 \%$.

Berdasarkan hasil uji kelayakan investasi peningkatan kapasitas PG Sragi penelitian ini akan menguji kembali dampak perubahan harga jual terhadap hasil perhitungan IRR sebelum dan sesudah kenaikan atau penurunan harga jual Gula dan Tetes

\section{Metode Penelitian}

Penelitian ini dapat dkelompokkan dalam jenis penelitian kuantitatif dengan menguji hubungan antar variabel. Data diambil Pabrik Gula Sragi. Hubungan variabel dan dapat dirumuskan dalam hipotesa sebagai berikut.

H1: Terdapat dampak yang positif antara kenaikan harga jual Gula dan Tetes terhadap hasil perhitungan IRR.

$\mathrm{H} 2$ : Terdapat dampak yang positif antara penurunan harga jual Gula dan Tetes terhadap hasil perhitungan IRR. 
H3 : Terdapat dampak yang positif antara kenaikan nila investasi terhadap hasil perhitungan IRR.

H4 : Terdapat dampak yang positif antara penurunan nila investasi terhadap hasil perhitungan IRR.

H5 : Terdapat dampak yang positif antara kenaikan Beban Pokok Produksi terhadap hasil perhitungan IRR.

H6 : Terdapat dampak yang positif antara penurunan Beban Pokok Produksi terhadap hasil perhitungan IRR.

\section{Hasil Penelitian dan Pembahasan}

\subsection{Pendanaan Investasi}

Pengajuan PMN pada tahun 2015 adalah peningkatan kapasitas PG Rendeng dari 2.800 TCD menjadi 4.000 TCD (225 Miliar), peningkatan kapasitas PG Mojo Sragen dari 2.800 TCD menjadi 4.000 TCD (225 Miliar) dan pembangunan pabrik baru berkapasitas 10.000 TCD (550 Miliar dan hutang jangka panjang 1.100 miliar). Pada kajian bersama Pabrik Gula baru di Comal-Pemalang dengan kapasitas 10.000 TCD, berdasarkan materi RDP pada bulan April 2015, luas areal yang diperlukan sebesar 16.903 Ha pada tahun 2019, namun kondisi tahun 2018/2019 diperkirakan sebesar 6.884 Ha. Berikut sebaran luas areal untuk pantura wilayah barat. Dalam kajian PT RPN-P3GI, total luas lahan tebu wilayah pantura tahun 2019 seluas 6.844 Ha sedangkan luas lahan maksimal diproyeksikan sebesar 15.000 Ha pada tahun 2028 .

Untuk menganalisis produksi dan finansial didasarkan pada kondisi daerah pantura barat dan bisnis gula saat ini. Untuk itu asumsi yang digunakan sesuai dengan analisis untuk PG Sragi. Berdasarkan analisis investasi pembangunan Pabrik Gula Baru dengan investasi sebesar 1.650 miliar menghasilkan nilai IRR 6,73\%, NPV -109 miliar (negatif), PI < 1, payback periode 6 tahun 9 bulan maka pembangunan pabrik baru tidak layak untuk kondisi bisnis saat ini. Kajian pada tahun 2017-2018 adalah pembangunan Pabrik Gula Comal Baru dengan kapasitas 6.000 TCD expandable 8.000 TCD. Seperti dalam kajian pabrik gula baru tahun 2015, asumsi yang digunakan mengikuti kondisi bisnis saat ini. Investasi yang dibutuhkan sebesar 1.661 miliar sehingga analisis investasi menghasilkan nilai IRR 6,63\%, NPV -118 miliar (negatif), PI < 1, payback periode 6 tahun 9 bulan maka pembangunan pabrik baru tidak layak untuk kondisi bisnis saat ini.

Berdasarkan analisis diatas, maka diperlukan kajian pemanfaatan dana PMN untuk revitalisasi pabrik gula eksisting. Alternatif penggunaan dana PMN untuk pabrik eksisiting sangat memungkinkan untuk PG Sragi, PG Pangka dan PG Tasikmadu. Untuk itu diperlukan analisis perbandingan antar 3 pabrik tersebut. Kinerja PG Sragi tahun 2011 - 2017, luas areal TS meningkat dari 45 Ha menjadi 634 Ha pada tahun 2017, luas areal TR menurun dari 5.505 Ha menjadi 1.157 Ha. Produktivitas tebu terendah sebesar 46,8 ton/Ha tertinggi 74,9 ton/Ha dengan kenaikan $6 \%$ per tahun. Rendemen rata-rata terendah $5,52 \%$ sedangkan tertinggi 7,10\%. Rendemen TS meningkat $1 \%$ sedangkan rendemen TR menurun sebesar $1 \%$. 


\subsection{Analisis Pengajuan PMN PG Sragi}

Untuk menganalisis program penggunaan dana PMN di PTPN IX telah dilakukan analisis dari sisi on farm, off farm dan keuangan. Berdasarkan ketiga aspek tersebut dapat diketahui bahwa ada sisi positif dan negatif pada masing - masing pilihan. Berikut kompilasi dari analisis tersebut.

Berdasarkan analisis tersebut, maka peningkatan kapasitas PG Sragi dan Peningkatan kehandalan PG Tasikmadu lebih efektif dan efisien dibandingkan dengan rencana pembangunan pabrik baru.

\subsection{Pengujian Kelayakan Investasi}

Aspek keuangan merupakan proyeksi keuangan dari aktivitas saat ini dan proyeksi investasi ke depan atas investasi PG Sragi yang pendanaannya bersumber dari realokasi PMN PG Comal. Aspek ini berkaitan dengan rencana perusahaan dalam meningkatkan kapasitas PG Sragi. Aspek keuangan meliputi sumber dan target pendapatan operasional serta biaya-biaya yang harus dikeluarkan meliputi biaya operasional produksi dan beban investasi yang dihitung dalam bentuk tabel lampiran proyeksi dan diuraikan dalam bentuk penjelasan dan kesimpulan. Selain itu, dibahas pula mengenai analisis kelayakan investasi untuk proyek tersebut sehingga dapat diketahui apakah proyek layak dilaksanakan atau tidak.

Penilaian kelayakan investasi proyek didasarkan atas nilai sekarang (Present Value $=P V$ ) dari jumlah laba bersih sesudah pajak ditambah nilai penyusutan yang diperoleh selama umur proyek (input), dibandingkan dengan nilai sekarang dari investasi yang dikeluarkan (output). Proyek disebut layak apabila pendapatan dimaksud lebih besar dari nilai investasi, dan disebut tidak layak apabila pendapatan tersebut lebih kecil dari pada nilai investasinya.

Yang dimaksud dengan umur proyek adalah umur teknis peralatan pabrik. Dalam analisa ini umur proyek diasumsikan sampai dengan nilai investasi peralatan pabrik habis disusut sehingga nilai buku sama dengan nol. Yang dimaksud dengan Proyek dalam hal ini adalah proyek pembangunan PG Sragi dengan kapasitas yang semula 3.000 TCD menjadi 4.000 TCD. Peralatan Pabrik Gula, kendaraan angkut dan gedung yang akan dibangun dan dibeli realisasinya tidak dapat dipisahkan satu sama lain, sehingga dalam analisis kelayakan keuangan proyek tersebut digabung menjadi satu proyek.

Beikut ini adalah uraian mengenai aspek keuangan:

\section{a. Rencana Keuangan}

Peningkatan kapasitas PG Sragi merupakan rencana investasi yang dilatar belakangi penataan kembali dan modernisasi Pabrik Gula yang ada di wilayah kerja PT Perkebunan Nusantara IX dan ketersediaan bahan baku tebu yang tersedia. Rencana Anggaran Biaya Proyek. Biaya proyek yang dibutuhkan meliputi biaya investasi.

\section{b. Rencana Sumber Dana}

Sumber dana proyek berupa kebutuhan biaya investasi yang didanai dari Penyertaan Modal Negara (PMN). 


\section{c. Proyeksi Keuangan}

Di dalam proyeksi keuangan terdapat asumsi-asumsi yang relevan atas aktivitas perusahaan saat ini maupun target-target yang akan dicapai untuk mengukur kemampuan perusahaan dalam memenuhi kewajibannya kepada pihak ketiga, serta mampu memenuhi kebutuhan operasional perusahaan. Asumsi-asumsi tersebut meliputi asumsi rencana hari giling pabrik, produksi gula milik PG, kebutuhan bahan baku tebu, harga jual gula dan tetes serta asumsi-asumsi lain yang relevan. Proyeksi keuangan yang menggambarkan mengenai rencana dan target-target aktivitas PG Sragi di masa mendatang tertuang dalam lampiran proyeksi pada laporan ini meliputi antara lain:
a. Rencana investasi
b. Rencana perolehan gula dan tetes milik PG
c. Target penjualan
d. Beban Pokok Produksi
e. Proyeksi Arus Kas (Cash flow).

\section{d. Asumsi Dalam Proyeksi}

Asumsi keuangan sebagai dasar perhitungan proyeksi keuangan dalam mengukur kelayakan dari rencana investasi untuk meningkatkan kapasitas PG Sragi adalah sebagai berikut:

a. Pabrik-Pabrik Gula Sumberharjo di wilayah kerja PT Perkebunan Nusantara IX tidak berproduksi untuk mendukung Bahan Baku Tebu PG Sragi.

b. Struktur pasar produk Gula Kristal Putih di pasar domestik diasumsikan bersaing sempurna (perfect competition) sehingga jumlah produk yang dihasilkan (termasuk tetes) PG Sragi tidak mempengaruhi harga pasar yang berlaku. Implikasi asumsi ini adalah berapapun kuantitas gula dan tets yang dihasilkan akan terjual pada tingkat harga pasar yang berlaku.

c. Rencana hari giling PG Sragi menyesuaikan ketersediaan bahan baku.

d. Kebutuhan bahan baku diperoleh dari kebun masyarakat sekitar lokasi PG dengan radius maksimal $50 \mathrm{~km}$ dengan total luas areal tanaman tebu sendiri dan Tebu Rakyat 7.435 Ha di tahun 2029 dimana produksi tebu 604.599 ton.

e. Bahan baku tebu diperoleh dari Tebu Sendiri dan Tebu Rakyat. Untuk Tebu Rakyat harga bahan baku tebu didasarkan pada bagi hasil antara PG dan petani yang ditentukan berdasarkan kualitas bahan baku tebu (rendemen).

f. Harga dasar penjualan gula sebesar Rp. 9.100,- per kg di tahun 2018 dan Rp9.700 per kg di tahun 2020 dengan kenaikan 1.5\% setiap tahun

g. Harga dasar penjualan tetes sebesar Rp. 1.200,- di tahun 2018 dan sebesar Rp 1.400,- di tahun 2020 per kg naik $1 \%$ setiap tahun

h. Asumsi DCF $8 \%$ dan tingkat pengembalian $12 \%$ per tahun.

i. Biaya produksi Perhitungan biaya produksi berdasarkan biaya on farm sebesar 40.000.000,- per ha, ditambah dengan biaya olah sebesar Rp 15.000,- per kuintal tebu, kedua biaya tersebut dibagi dengan rendemen.

j. Asumsi rendemen bahan baku terhadap produksi sebagai berikut:

1. Rendemen pada tahun 2029 sebesar $8,61 \%$ dengan rata - rata $8,16 \%$,

2. Produktivitas tebu tahun 2029 sebesar 81,32 ton/Ha dengan rata -rata 79,78 ton/Ha. 


\subsubsection{Terdapat dampak yang positif antara kenaikan harga jual Gula dan Tetes terhadap hasil perhitungan IRR.}

Hasil analisis sensitivitas menunjukkan besarnya IRR $=18,61 \%$ hal ini berarti bila harga jual nail $10 \%$ akan berpengaruh pada kenaikan laba sebesar 5,86\% atau kenaikan IRR dari $12,75 \%$ menjadi $18,61 \%$. Hasil pengujian disajikan pada tabel 4.1. berikut:

Tabel 4.1.

Hasil Uji Sensitivitas

\begin{tabular}{|l|r|r|l|}
\hline Aspek & \multicolumn{1}{|c}{$-10 \%$} & \multicolumn{1}{l}{ BASE } & $10 \%$ \\
\hline HARGA JUAL & $5,82 \%$ & $12,75 \%$ & $18,61 \%$ \\
\hline HPP & $13,25 \%$ & $12,75 \%$ & $12,15 \%$ \\
\hline INVESTASI & $14,68 \%$ & $12,75 \%$ & $11,07 \%$ \\
\hline
\end{tabular}

\subsubsection{Terdapat dampak yang positif antara penurunan harga jual Gula dan Tetes} terhadap hasil perhitungan IRR.

Hasil analisis sensitivitas dari hipotesis harga jual turun $10 \%$ menunjukkan besarnya IRR $=5,82 \%$ hal ini berarti bila harga jual turun $10 \%$ akan berpengaruh pada penurunan laba sebesar $6,93 \%$ atau penurunan IRR dari $12,75 \%$ menjadi $5,82 \%$. Hasil pengujian disajikan pada tabel 4.1. dan grafik 1. berikut:

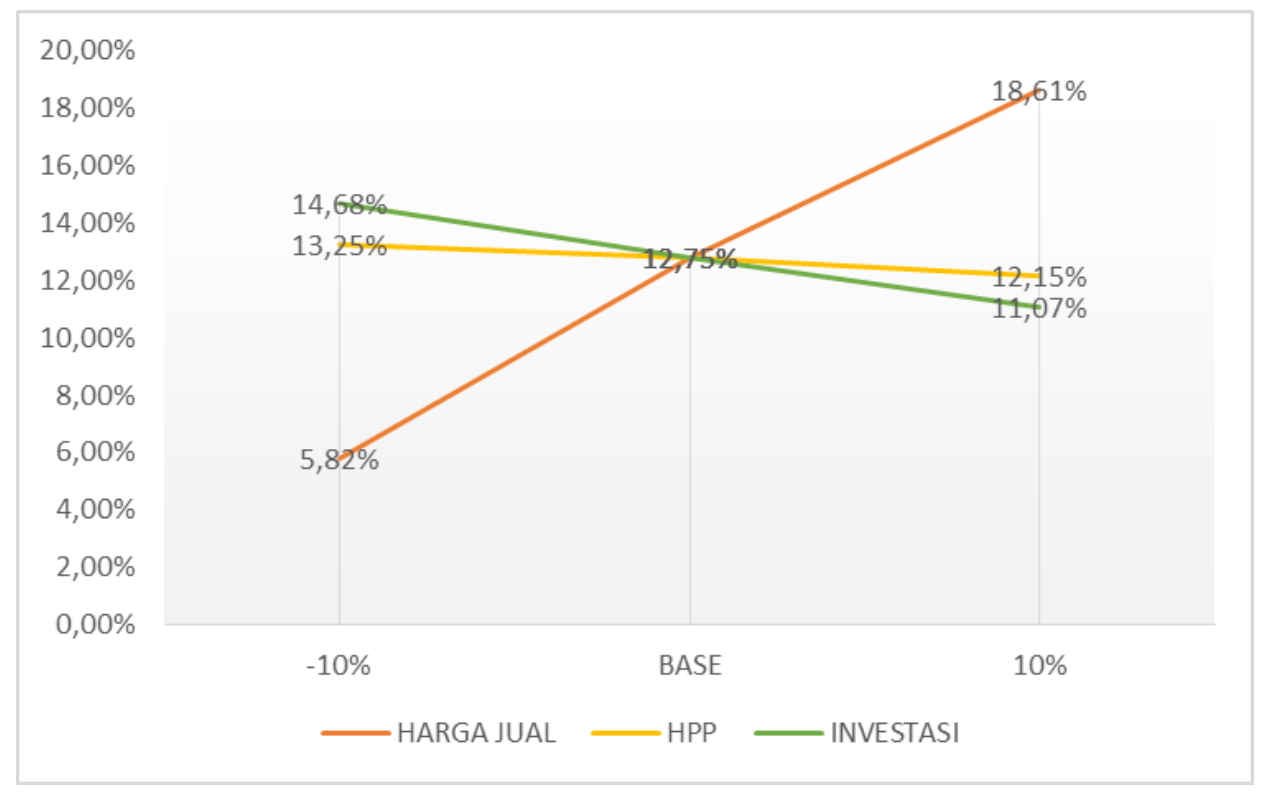

Gambar 1 Analisis sensitivitas revitalisasi PG Sragi

\subsubsection{Terdapat dampak yang positif antara kenaikan nila investasi terhadap hasil perhitungan IRR.}

Hasil analisis sensitivitas dari hipotesis seandainya ada kenaikan nilai investasi $10 \%$ menunjukkan besarnya IRR $=11,07 \%$ hal ini berarti bila ada kenaikan nilai investasi 
$10 \%$ maka akan berpengaruh pada penurunan laba sebesar $1,68 \%$ atau penurunan IRR dari $12,75 \%$ menjadi $11,07 \%$. Hasil pengujian disajikan pada tabel 4.1. dan grafik 1.

\subsubsection{Terdapat dampak yang positif antara penurunan nila investasi terhadap hasil perhitungan IRR.}

Hasil analisis sensitivitas dari hipotesis seandainya ada penurunan nilai investasi $10 \%$ menunjukkan besarnya IRR $=14,68 \%$ hal ini berarti bila ada penurunan dari nilai investasi $10 \%$ maka akan berpengaruh pada kenaikan laba sebesar 1,93\% atau kenaikan IRR dari $12,75 \%$ menjadi $14,68 \%$. Hasil pengujian disajikan pada tabel 4.1. dan grafik 1 .

\subsubsection{Terdapat dampak yang positif antara kenaikan Beban Pokok Produksi terhadap hasil perhitungan IRR.}

Hasil analisis sensitivitas dari hipotesis seandainya ada kenaikan Beban Pokok Produksi $10 \%$ menunjukkan besarnya IRR $=12,15 \%$ hal ini berarti bila ada kenaikan dari biaya produksi $10 \%$ maka akan berpengaruh pada penurunan laba sebesar $0,60 \%$ atau penurunan IRR dari $12,75 \%$ menjadi $1215 \%$. Hasil pengujian disajikan pada tabel 4.1. dan grafik 1.

\subsubsection{Terdapat dampak yang positif antara penurunan Beban Pokok Produksi terhadap hasil perhitungan IRR.}

Hasil analisis sensitivitas dari hipotesis seandainya ada penurunan Beban Pokok Produksi $10 \%$ menunjukkan besarnya IRR $=13,25 \%$ hal ini berarti bila ada penurunan biaya produksi $10 \%$ maka akan berpengaruh pada kenaikan laba sebesar $0,50 \%$ atau kenaikan IRR dari 12,75\% menjadi 13,25\%. Hasil pengujian disajikan pada tabel 4.1. dan grafik 1 .

Hasil penelitian ini tidak mendukung hasil penelitian sebelumnya bahwa variabel harga jual mempunyai sensitivitas tertinggi dibanding variable yang lain, M. Dion Tiara dkk (2016) Magister Agribisnis Program Pascasarja UNS meneliti dengan judul Analisis Investasi Konversi Komodits kopi ke Karet di PT Perkebunan Nusantara IX Kebun Batujamus. Hasilnya komoditas Kopi lebih peka terhadap perubahan harga jual dan biaya operasional dibandingkan dengan karet. Hal tersebut terlihat pada penurunan harga jual kopi sebesar $10 \%$ dan kenaikan biaya $10 \%$.

Penelitian keempat Peremajaan Optimal Tanaman Karet di PT Perkebunan Nusantara IX Kebun Getas oleh Titik Widyasari,dkk (UGM, 2015). Hasilnya respon peremajaan optimal terhadap penurunan harga 5-10\% dan kenaikan biaya 5-10\% secara bersamaan, menunjukkan bahwa saat optimal peremajaan Tanaman karet tetap di tahun ke-25 dan pola optimum yang tepat di \% dari luasan lahan.

Hifhil Ramadhan dan Suwandhi (2019) menguji sensitivitas harga jual, biaya produksi dan jumlah produksi terhadap profitabilitas PG Tasikmadu PT Perkebunan Nusantara IX. Hasilnya membuktikan bahwa perubahan harga jual yang paling peka terhadap ROI, kemudian jumlah produksi dan yang paling rendah perubahan biaya produksi terhadap ROI. 


\section{Simpulan dan Saran}

Berdasarkan hasil pengujian hipotesis menggunakan analisis regresi berganda sebagaimana telah dibahas sebelumnya dapat disimpulkan sebagai berikut.Pertama,kenaikan harga jual menunjukkan sensitivitas tertinggi atau paling sensitive terhadap perubahan IRR dari $12,75 \%$ naik menjadi $18,61 \%$. Sedangkan penurunan harga jual akan berpengaruh pada penurunan laba sebesar 6,93\% atau penurunan IRR dari $12,75 \%$ menjadi $5,82 \%$. Kedua,kenaikan nilai investasi yang berpengaruh kedua setelah kenaikan harga jual. Apabila ada kenaikan nilai investasi $10 \%$ maka akan berpengaruh pada IRR dari $12,75 \%$ menjadi $11,07 \%$. Sebaliknya apabila nilai investasi turun $10 \%$ maka akan berpengaruh pada kenaikan IRR dari $12,75 \%$ menjadi 14,68\%.Ketiga, untuk Beban Pokok Produksi menjadi urutan ketiga kepekaannya bila ada kenaikan biaya produksi $10 \%$ maka akan berpengaruh pada penurunan IRR dari $12,75 \%$ menjadi $1215 \%$. Sedangkan apabila ada kenaikan Beban Pokok Produksi 10\% maka akan peka terhadap kenaikan IRR dari 12,75\% menjadi 13,25\%.

\section{Daftar Pustaka}

Asuad, Husnan, 2000. Manajemen Keuangan, Edisi ke-4, BPFE, Yogyakarta,

Bujarati, D.,1995. Basic Econometrics, Third Edition, Mc-Grawhill, New York,

Buzali, Imam, 2001 Aplikasi Analisis Multivariate Dengan Program SPSS, Badan Penerbit Undip,

Dion, Tiara, dkk.2013. Analisis investasi konversi Kopi ke karet di PT Perkebunan Nusantara IX, Agribusiness Review, 1 (1).

Ekahyudi, Prasetya, 2010.Analisis Break Even Point Pada Industri Pengolahan Tebu di Pabrik Gula Mojo, PT Perkebunan Nusantara IX, Skripsi, UNS, 2010

Fiyanto, Bambang, 2012.Dasar-dasar Pembelanjaan Perusahaan, Edisi 4, BPFE, Yogyakarta

Galfasan, Replesia, 2018. Analisis Sensitivitas Produksi Kopi Sambung,Yogya, Kanisius.

Gunfidza,dkk. 2015.Analisis Profitabilitas Kebun Karet Balong PT Perkebunan Nusantara IX, MEDIA GRO, Vol 11 No 2 Tahun 2015.

Hin, Rismawati. 2009. Sensitivitas Perbaikan Mesin dalam Sistem Manufaktur, Tesis, Universitas Sumatera Utara (USU). 
